\title{
Satellite imagery, a base line for glacier variation study on James Ross Island, Antarctica
}

\author{
Pedro SkVArca, \\ Instituto Antartico Argentino, Cerrito 1248, 1010 Buenos Aires, Argentina \\ Helmut Rott and Thomas Nagler \\ Institut für Meleorologie und Geophysik der Universiläl Innsbruck, Innrain 52, A-6020 Innsbruck, Austria
}

\begin{abstract}
Sequential visible and radar satellite imagery is used to document the fluctuations of 39 outlet glaciers on James Ross Island (JRI; $64^{\circ} \mathrm{S}, 58^{\circ} \mathrm{W}$ ), Antarctic Peninsula. The monitoring time interval of 17.4 years extends from late 1975 until early 1993. The study is based on synergistic use of different sensors for monitoring glacier variations. The digitally enhanced Landsat TM images also allowed definition of boundaries between grounded and floating ice within Röhss Bay and detection of ice rumples, resulting in an improved measurement of the areal extent of JRI. In addition to glacier boundaries, the analyzed ERS-1 SAR images provide information on morphological properties of snow and ice. The satellite data show a general glacier retreat since 1975, resulting in clear decrease of overall glacier area on JRI. Of 39 glaciers measured, 33 glaciers retreated in the period 1975-93, 15 of which showed significant retreat in comparison to glacier size. This is in accordance with the pronounced atmospheric-warming trend recorded during the last two decades on the Antarctic Peninsula. The analysis of glacier areas on JRI thus provides a base line for detection of future changes.
\end{abstract}

\section{INTRODUCTION}

James Ross Island (JRI) is located on the northeastern end of the Antarctic Peninsula; it extends north-south from Cape Lachman $\left(63^{\circ} 47^{\prime} \mathrm{S}\right)$ to Cape Foster $\left(64^{\circ} 27^{\prime} \mathrm{S}\right)$ and east-west from Cape Gage $\left(57^{\circ} 04^{\prime} \mathrm{W}\right)$ to Tumbledown Cliffs $\left(58^{\circ} 28^{\prime} \mathrm{W}\right.$ ) (Fig. 1). The main part of the island is covered by a single ice cap of $200-300 \mathrm{~m}$ in thickness, with the highest elevation of $1609 \mathrm{~m}$ at Mount Haddington (IGM, 1992). The ice cap is cold-based (Aristarain and others, 1990) and drains mainly over steep-to-vertical curved cliffs, giving origin to outlet glaciers that extend into the sea. Most of these outlet glaciers terminate in wide calving ice fronts. Ice and snow at lower elevations are strongly affected by summer melt. Mean accumulation rates, measured at altitudes above $1190 \mathrm{~m}$, show strong variations, with geographic distribution probably influenced by the southwesterly winds (Aristarain and others, 1987).

Most of the glaciers that terminate on the land are located north of $64^{\circ} \mathrm{S}$ latitude, in the predominantly icefree part of the island, and are not connected to the main ice cap. A few additional glaciers that end on land are found near the eastern and western coasts. Many of these low-altitude glaciers are polythermal-type glaciers, partially wet-based, developing both shear and push moraines (Strelin and Malagnino, 1992). Rabassa and others (1982) have compiled a preliminary glacier inventory, classifying in total 138 glaciers of different types for JRI.
In this paper we present data on recent variations of 39 outlet glaciers distributed around the island, most of which are terminating with floating or partially floating fronts. Only part of the glaciers terminating over land could be analyzed, due to masking by snow cover on some parts of the island in the visible and near-infrared images, and due to terrain distortions in SAR images. This limited analysis, based on Landsat Multispectral Scanner (MSS) images with $79 \mathrm{~m}$ spatial resolution and on Landsat Thematic Mapper (TM) images with $28 \mathrm{~m}$ spatial resolution, indicated no pronounced change for small land-based glaciers within the period 1977-88.

The synthetic aperture radar (SAR) system, in earth orbit on the European Remote Sensing Satellite, ERS-1, since July 1991, offers improved temporal resolution for monitoring areal extent and properties of glaciers (Rott and others, 1993, 1994; Rott and Nagler, 1994). This study is based on SAR and on visible and near-infrared satellite imagery, demonstrating the usefulness of SAR for glacier studies as well as the potential of synergism of different sensors for monitoring glacier variations.

\section{DATA SOURGES AND ANALYSIS}

The available data set includes: Kosmos KATE-200 image acquired on 3 October 1975 film No. 1064, frame No. 596); Landsat MSS images acquired on 31 January 1977 (path/row 229/105 and 229/106); Landsat TM 


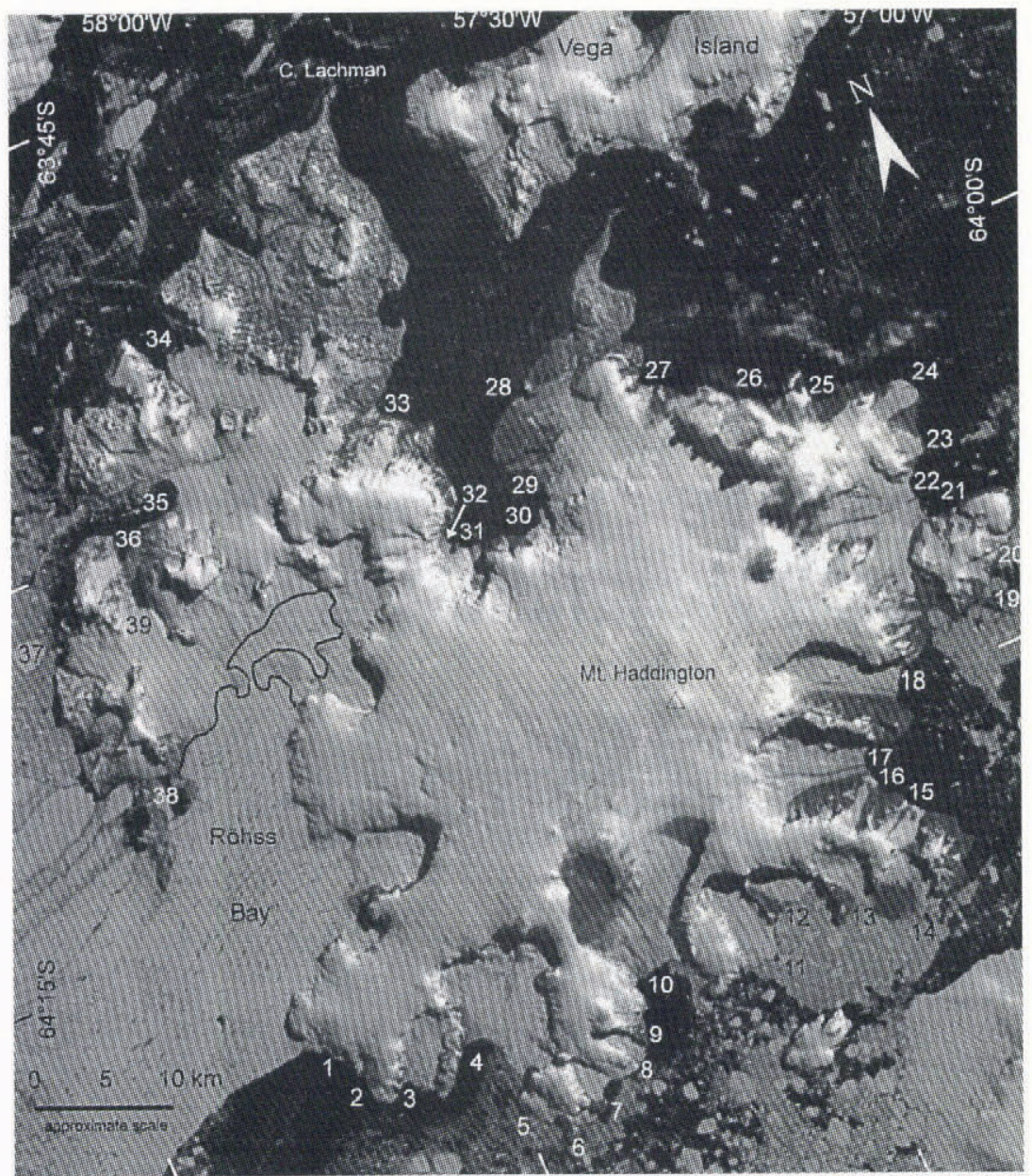

Fig. 1. Section of Landsal TM image ID 42054-12162-4, band 4, of 29 February 1988, showing James Ross Island. The numbers 1-39 indicate the outlet glaciers referred to in the text and in Table 1. The black line in the northeastern part of Röhss Bay corresponds to the grounding line. (Reproduced by permission of EOSAT.)

image acquired on 29 February 1988 (215/105); Landsat TM image acquired on 5 November 1989 (216/105); and ERS-1 SAR images of 13 February 1993 (orbit/frame 8270/4923 and 8270/4941). Additional ERS-1 SAR images, covering only parts of JRI, were acquired during the periods January-February 1992, July-August 1992, December 1992-January 1993 and August 1993. Parts of these ERS-1 SAR images have also been available for this study. The main analysis was based on the pair of ERS-1 SAR images of 13 February 1993, because the island was completely covered by both images and because the boundaries of the glaciers appeared clearly on this date due to the absence of sea ice.

The very first spaceborne image of JRI was acquired on 3 October 1975, with the KATE-200 optical camera on board a Kosmos satellite. This image was selected as the starting point for analyzing the glacier fluctuations around JRI. A copy of the original image became available as a photographic negative through Sojuzkarta. The nominal resolution of KATE-200 photographs is specified as 15$30 \mathrm{~m}$, depending on the orbital altitude of the satellite. The negative of the $600-700 \mathrm{~nm}$ spectral channel was selected for the analysis because it showed better contrast than the other two channels. The photographic product was digitized to enable combined analysis with the other satellite data which were obtained in digital form.
Digitization was carried out with over-sampling in order not to lose spatial resolution. In addition, this enabled the analysis of point-spread functions to derive the actual spatial resolution which was found to be about $50 \mathrm{~m}$. This value is poorer than the specification, possibly as result of degradation in the photographic copying and enlargement process.

Of the available optical imagery, the TM image of 29 February 1988 showed the least areal extent of snow on the land surfaces and of sea-ice cover (Fig. 1). For this reason, and due to the comparatively high spatial resolution of TM, this image was selected as the geometric reference to which the other satellite images were coregistered. The TM pixel size, corresponding approximately to the instantaneous field of view on ground (IFOV), is $28.5 \mathrm{~m} \times 28.5 \mathrm{~m}$, whereas the MSS pixel size is $79 \mathrm{~m} \times 79 \mathrm{~m}$. In addition, TM with three channels in the visible, one channel in the near-infrared, two channels in the mid-infrared and one channel in the thermal infrared shows the best spectral capabilities for discriminating snow, ice, snow-free surfaces and clouds. MSS has two visible and two near-infrared channels, thus offering better spectral contrast between the various targets than the monochromatic KATE image.

SAR Ellipsoid Geocoded Images (ERS-1.SAR.GEC) of ERS-1 were obtained from the European Space 
Agency; these images were acquired at the Antarctic receiving station at O'Higgins (ESA, 1993). ERS-1 SAR operates at $5.3 \mathrm{GHz}(5.7 \mathrm{~cm}$ wavelength $)$; a single image covers an area of $100 \mathrm{~km} \times 100 \mathrm{~km}$. The pixel size of a GEC image is $12.5 \mathrm{~m} \times 12.5 \mathrm{~m}$. The spatial resolution of ERS-1 SAR is $25 \mathrm{~m}$ in ground range and $25 \mathrm{~m}$ in azimuth direction, with three independent azimuth looks. The image is rectified onto a map projection assuming flat earth and radiometrically calibrated, enabling derivation of quantitative back-scatter values. Because the image is not corrected for terrain effects, considerable geometric distortions result in areas with medium-to-high relief. Particularly disturbing are shortening "fore-shortening") and lay-over of slopes facing towards the radar antenna. Accurate digital elevation data, with grid size comparable to the scale of the SAR pixels, are needed for terrain-corrected geocoding. Such data are not available for the investigation area. Therefore, the analysis of glacier boundaries was carried out only for glaciers terminating at sea and thus close to sea level.

In addition to ice boundaries, information on surface and sub-surface properties of snow and ice can be derived from SAR images. Figure 2 shows the southwestern corner of JRI in the ERS-1 SAR image of 13 February 1993. The boundaries of the floating glacier termini towards the ocean can be clearly identified because the wind-roughened sea, which was partly covered by scattered sea-ice floes, gave rise to higher back-scattering coefficients than the glaciers. The back-scattering coefficients $\sigma^{\circ}$ of the glaciers near the boundaries were around $-8 \mathrm{~dB}$ which is typical for rough glacier ice at Cband. The lower parts of the glaciers (below the ice cliffs) show the lowest $\sigma^{\circ}$ values (about $-17 \mathrm{~dB}$ ); similar values were observed for wet summer snow on Alpine glaciers (Rott and Nagler, 1994). $\sigma^{\circ}$ values between 0 and $-2 \mathrm{~dB}$ observed on the ice cap at elevations above about $1000 \mathrm{~m}$ a.s.l. indicate refrozen firn (percolation facies). This signal is made up by scattering contributions from the snow volume down to several meters depth because of low dielectric losses in dry snow. Ice pipes and ice layers in the frozen-snow volume act as strong scatterers Rott and others, 1993, 1994). At elevations below $1000 \mathrm{~m}$ the $\sigma^{\circ}$ values are gradually decreasing with decreasing altitudes, down to values around $-10 \mathrm{~dB}$ near the margin of the firn plateau of the ice cap at an elevation of about $500 \mathrm{~m}$. This decrease of $\sigma^{\circ}$ can be explained by slowly increasing wetness of the snowpack Rott and others, 1988). In ERS-I SAR images acquired during the winter, all parts of the accumulation zone reveal high backscattering values as typical for frozen percolation facies.

For co-registering of the various images to the TM image of 29 February 1988, between 50 and 100 control points on ice-free surfaces around the island were selected for each registration process. For co-registration of SAR with visible and near-infrared imagery all control points were selected on the coast, which means that the co-

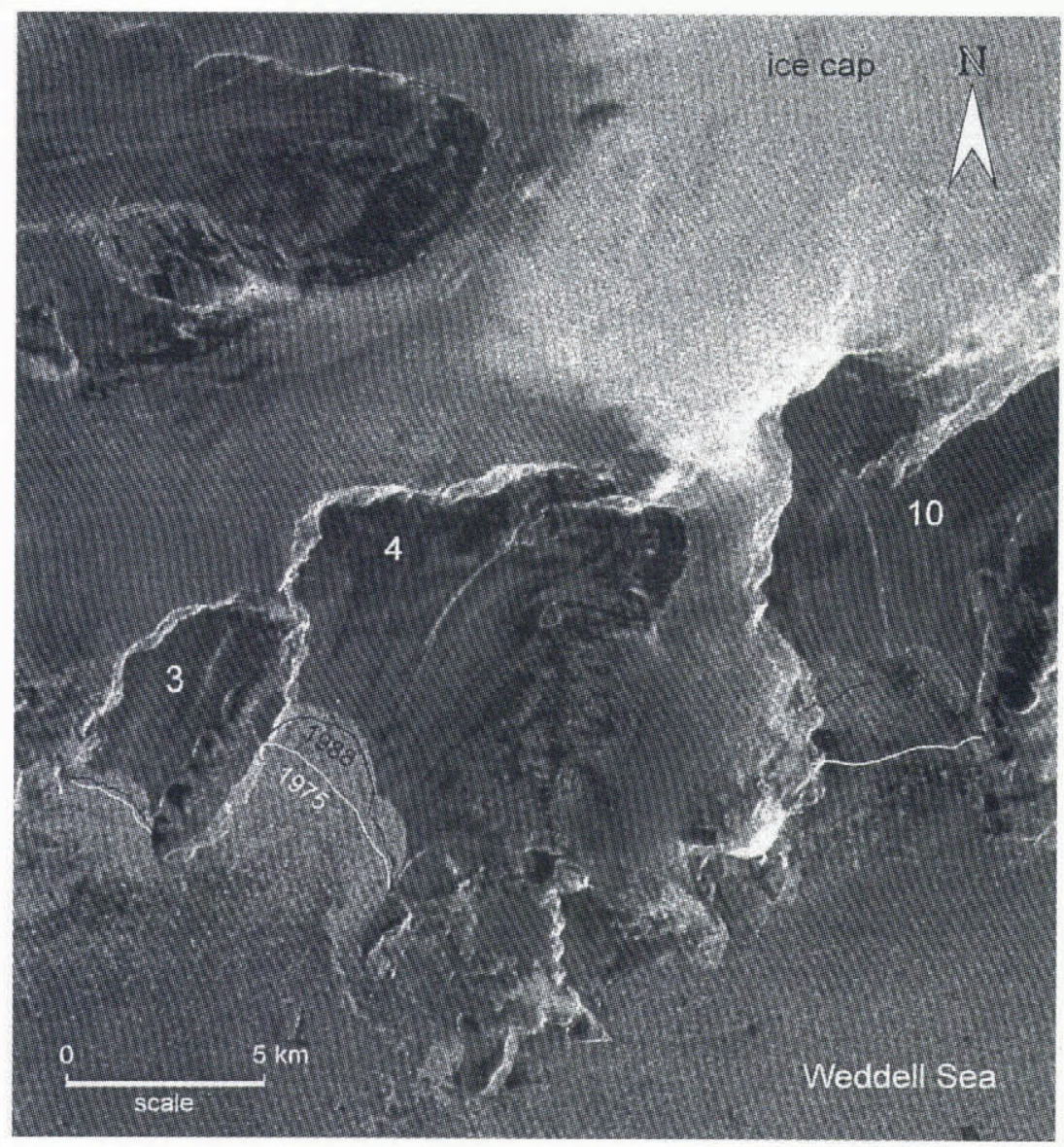

Fig. 2. Section of ERS-1 SAR images of 13 February 1993 (orbit 8270, frames 4923 and 4941) showing the southwest comer of James Ross Island. The while lines in front of glaciers 3, 4 and 10 correspond to the boundaries in 1975, the black lines to the boundaries in 1988. (Copyright C) 1993 ESA.) 
registration is accurate only at sea level. The residual rms errors in range and azimuth direction of the control points in the co-registered images were: $17 \mathrm{~m}$ for TM-TM registration, $63 \mathrm{~m}$ for MSS-TM registration, $45 \mathrm{~m}$ for KATE-TM registration, $52 \mathrm{~m}$ for SAR-TM registration. Considering the high spatial resolution of both sensors, the rms error is comparatively high for co-registration of SAR and TM, coming close to the error for MSS-TM and KATE-TM registration. This can be explained by problems in the identification of co-located targets in SAR and visible/near-infrared imagery resulting from different interaction mechanisms governing radar backscattering and optical reflectivity (Rott and others, 1988).

\section{CHANGES OF GLACIER EXTENT}

The variations of the extent of 39 glaciers for the periods 1975-88 and 1988 93, based on analysis of the KATE200 image from 3 October 1975, the Landsat TM image from 29 February 1988, and the ERS-1 SAR images from 13 February 1993, are summarised in Table 1. A small part of the 1988 TM image (glaciers 25 and 26) was covered by clouds; these glaciers were analyzed in the 1989 TM image instead. The locations of the glaciers are indicated in Figure 1, on band $4(760-900 \mathrm{~nm})$ of the TM image. One of the glaciers listed in the table (No. 39, Aguas Claras) calves into a fresh-water lake Hidden Lake), located on the west side of JRI. Thirty-three of the glaciers are tide-water calving glaciers, most of them floating $(\mathrm{F})$ or partially afloat $(\mathrm{PF})$. Five glaciers were found to be grounded $(\mathrm{G})$. The classification of glacier type was possible through the interpretation of digitally enhanced TM images of 1988 and 1989 which allowed detection of grounding zones based on image brightness and texture related to subtle variations of surface topography.

The digital enhancement of these scenes also helped to define the boundaries between grounded glacier ice and floating ice (ice shelf) within Röhss Bay (Fig. 1) as well as to identify the ice rumples located in the northeastern part of the bay. With this more accurate position of the coastline in Röhss Bay, the extent of JRI was measured digitally from the TM images, resulting in total area of $2478 \mathrm{~km}^{2}$. This value is slightly higher than the number given by Rabassa and others (1982), who classified 18.6\% of the island as ice-free. All glaciers draining into Röhss Bay are still protected by the small, thin ice shelf within the Prince Gustav Channel which was connected with the main part of Larsen Ice Shelf until 1957/58. The southern and northern limits of this remnant ice shelf are presently rapidly retreating (Skvarca, 1993).

For the period 197588 only nine small-to-mediumsized glaciers, comprising $25 \%$ of the outlet glaciers considered, show no changes or changes too small to be identified with the available satellite imagery. The remaining glaciers exhibit a general recessionary trend which is significant in some cases. For the total time interval extending over 17.4 years (1975-93) only six of the glaciers monitored remain unchanged at their front. During the period 1975-88 (12.4 years) the total decrease of glacier area was $22.8 \mathrm{~km}^{2}$, whereas during the period 1988-93 (4.95 years) the net areal loss amounted to
$10.3 \mathrm{~km}^{2}$. During this shorter period three glaciers (Nos. 11,12 and 17) showed a slight advance which may be due to short-term fluctuations of the floating fronts. During the period 1975-93 the glacier area on JRI was reduced in total by $33.1 \mathrm{~km}^{2}$.

By comparing the two investigation periods, it is obvious that the general trend of recession is continuing. About one-third of the glaciers show an accelerated rate of retreat during the second period. For some glaciers the retreat rate increases considerably, as for glacier 3 (see Table 1), located on the southern part of JRI (Fig. 2). Four glaciers show nearly the same recession rate in both periods, whereas for another one-third of the glaciers the rate of retreat slows down slightly. Only glaciers 26 and 32 show a pronounced decrease in the rate of recession.

It should be noted that Hobbs Glacier (No. 17) and Gordon Glacier (No. 18), located near each other, show different behaviours for the period 1988-93. While Hobbs Glacier was slightly advancing, Gordon Glacier exhibited an accelerated rate of recession, with the area loss during the second time interval ( 4.95 years) almost the same as during the previous 12.4 years.

In summary, it is evident that the general recession monitored since late 1975 resulted in a clear decrease of glacier area on JRI. This is in accordance with the pronounced atmospheric warming of about $1^{\circ} \mathrm{C}$ observed in the region of the Antarctic Peninsula during the last two decades, as revealed by temperature data from nearby stations (Hoffmann, 1991), as well as by the icecore climatic history from Dyer Plateau (Thompson and others, 1995).

\section{CONCLUSIONS}

The analysis of glacier areas on JRI shows a consistent retreat of the glaciers in the past two decades and provides a baseline for detection of future changes within a region with a pronounced warming trend. In addition to a rise in atmospheric temperature, changes of ocean circulation and/or temperature may be of importance for the observed glacier behaviour because all major changes in glacier extent were observed for floating termini. Most of the JRI tide-water outlet glaciers show considerable retreat during the period 1975-93, as derived from analysis of sequential satellite imagery. The exceptions are the glaciers draining into Röhss Bay, which are still protected by the small remnant ice shelf in the Prince Gustav Channel. During the 5 year period 198893 three of the glaciers, located on the southeastern side of JRI, show a small increase in area after clear retreat in the previous period.

The data presented demonstrate the utility of satellite images from different sensors for monitoring glacier variations in remote areas where other data are scarce or do not exist. Among the available satellite sensors with high spatial resolution, synthetic aperture radar (SAR) offers the best capabilities for regular glacier observations and close time sequences in regions with frequent cloudiness. In addition to glacier boundaries, SAR is able to provide information on structural and morphological properties of snow and ice which are of glaciological and climatic relevance. 
Table 1. Ice-front variations of 39 outlet glaciers on JRI, 1975-88 and 1988-93, derived from salellite data. Geographic coordinates of glacier front (in 1975) from lopographic chart 1: 100000 (IGM, 1992). Glacier widlh from 1988 TM image. F, floating; PF, partly floating; G, grounded. Named glaciers are: Tait (4), Swift (10), Hobbs (17), Gourdon (18), Coley (22), Gringo (30), Gama (33), Reichert (35), Villar Fabre (37), Aguas Claras (39).

\begin{tabular}{|c|c|c|c|c|c|c|c|c|}
\hline \multirow{3}{*}{$\begin{array}{c}\text { Glacier } \\
\text { No. }\end{array}$} & \multirow[t]{2}{*}{ Lat. } & \multirow[t]{2}{*}{ Long. } & \multirow[t]{2}{*}{ Width } & \multirow[t]{3}{*}{ Type } & \multicolumn{2}{|c|}{ Retreat } & \multicolumn{2}{|c|}{ Rate of retreat } \\
\hline & & & & & $1975-88$ & $1988-93$ & 197588 & $1988-93$ \\
\hline & ${ }^{\circ} \mathrm{S}$ & ${ }^{\circ} \mathrm{W}$ & $\mathrm{km}$ & & \multicolumn{2}{|c|}{$\mathrm{km}^{2}$} & \multicolumn{2}{|c|}{$\mathrm{km}^{2} \mathrm{a}^{-1}$} \\
\hline 1 & 64.36 & 58.24 & 0.85 & $\mathrm{~F}$ & 0.00 & 0.00 & 0.00 & 0.00 \\
\hline 2 & 64.39 & 58.20 & 0.81 & $\mathrm{~F}$ & 0.00 & 0.32 & 0.00 & 0.06 \\
\hline 3 & 64.38 & 58.16 & 2.38 & $\mathrm{~F}$ & 0.27 & 1.27 & 0.02 & 0.26 \\
\hline 4 & 64.39 & 58.05 & 4.54 & $\mathrm{~F}$ & 4.19 & 1.88 & 0.34 & 0.38 \\
\hline 5 & 64.43 & 58.01 & 1.89 & $\mathrm{PF}$ & 0.00 & 0.00 & 0.00 & 0.00 \\
\hline 6 & 64.44 & 57.94 & 1.39 & $\mathrm{~F}$ & 0.00 & 0.05 & 0.00 & 0.01 \\
\hline 7 & 64.43 & 57.91 & 1.73 & $\mathrm{~F}$ & 0.08 & 0.22 & 0.01 & 0.04 \\
\hline 8 & 64.42 & 57.84 & 1.22 & PF & 0.18 & 0.06 & 0.01 & 0.01 \\
\hline 9 & 64.39 & 57.82 & 0.81 & $\mathrm{G}$ & 0.05 & 0.00 & 0.00 & 0.00 \\
\hline 10 & 64.38 & 57.76 & 4.36 & $\mathrm{~F}$ & 6.29 & 3.30 & 0.51 & 0.67 \\
\hline 11 & 64.38 & 57.60 & 2.61 & $\mathrm{~F}$ & 0.56 & -0.28 & 0.05 & -0.06 \\
\hline 12 & 64.36 & 57.55 & 2.89 & $\mathrm{~F}$ & 0.37 & 0.16 & 0.03 & -0.03 \\
\hline 13 & 64.37 & 57.47 & 1.58 & $\mathrm{~F}$ & 0.31 & 0.00 & 0.02 & 0.00 \\
\hline 14 & 64.39 & 57.39 & 1.71 & $\mathrm{PF}$ & 0.55 & 0.07 & 0.04 & 0.01 \\
\hline 15 & 64.33 & 57.35 & 1.57 & G & 0.00 & 0.00 & 0.00 & 0.00 \\
\hline 16 & 64.30 & 57.39 & 0.93 & G & 0.05 & 0.00 & 0.00 & 0.00 \\
\hline 17 & 64.29 & 57.39 & 1.89 & $\mathrm{~F}$ & 0.64 & -0.23 & 0.05 & -0.05 \\
\hline 18 & 64.25 & 57.31 & 2.45 & $\mathrm{~F}$ & 0.49 & 0.47 & 0.04 & 0.09 \\
\hline 19 & 64.21 & 57.14 & 0.84 & PF & 0.00 & 0.00 & 0.00 & 0.00 \\
\hline 20 & 64.19 & 57.10 & 0.58 & PF & 0.04 & 0.00 & 0.00 & 0.00 \\
\hline 21 & 64.15 & 57.13 & 0.65 & $\mathrm{~F}$ & 0.10 & 0.00 & 0.01 & 0.00 \\
\hline 22 & 64.14 & 57.18 & 2.83 & $\mathrm{~F}$ & 1.72 & 0.67 & 0.14 & 0.14 \\
\hline 23 & 64.12 & 57.17 & 1.00 & $\mathrm{~F}$ & 0.03 & 0.10 & 0.00 & 0.02 \\
\hline 24 & 64.08 & 57.16 & 2.02 & $\mathrm{~F}$ & 0.16 & 0.05 & 0.01 & 0.01 \\
\hline 25 & 64.07 & 57.28 & 1.58 & $\mathrm{~F}$ & 0.25 & 0.06 & 0.02 & 0.01 \\
\hline 26 & 64.05 & 57.36 & 2.47 & $\mathrm{~F}$ & 1.44 & 0.04 & 0.12 & 0.01 \\
\hline 27 & 64.02 & 57.50 & 0.92 & $\mathrm{PF}$ & 0.00 & 0.03 & 0.00 & 0.01 \\
\hline 28 & 64.00 & 57.70 & 1.28 & $\mathrm{~F}$ & 0.36 & 0.07 & 0.03 & 0.01 \\
\hline 29 & 64.05 & 57.70 & 1.26 & $\mathrm{PF}$ & 0.06 & 0.02 & 0.00 & 0.00 \\
\hline 30 & 64.08 & 57.73 & 2.32 & $\mathrm{~F}$ & 0.06 & 0.18 & 0.00 & 0.04 \\
\hline 31 & 64.08 & 57.81 & 1.86 & $\mathrm{~F}$ & 0.42 & 0.64 & 0.03 & 0.13 \\
\hline 32 & 64.07 & 57.84 & 1.35 & $\mathrm{~F}$ & 0.72 & 0.04 & 0.06 & 0.01 \\
\hline 33 & 63.99 & 57.86 & 0.73 & G & 0.00 & 0.00 & 0.00 & 0.00 \\
\hline 34 & 63.90 & 58.13 & 2.63 & $\mathrm{~F}$ & 0.85 & 0.32 & 0.07 & 0.06 \\
\hline 35 & 63.98 & 58.20 & 2.62 & $\mathrm{~F}$ & 2.08 & 0.61 & 0.17 & 0.12 \\
\hline 36 & 64.01 & 58.30 & 0.69 & G & 0.00 & 0.00 & 0.00 & 0.00 \\
\hline 37 & 64.06 & 58.43 & 1.77 & $\mathrm{~F}$ & 0.39 & 0.08 & 0.03 & 0.02 \\
\hline 38 & 64.14 & 58.37 & 2.14 & $\mathrm{~F}$ & $* *$ & 0.45 & $* *$ & 0.09 \\
\hline 39 & 64.05 & 58.29 & 0.97 & $F^{*}$ & 0.05 & 0.00 & 0.00 & 0.00 \\
\hline
\end{tabular}

In lake.

** Glacier attached to the ice shelf in 1975 .

\section{ACKNOWLEDGEMENTS}

The investigations at the University of Innsbruck were supported by the Austrian Science Fund (FWF) Project P8476. The European Space Agency made available the ERS-1 SAR data for AO experiment No. A2.

\section{REFERENCES}

Aristarain, A.J., J. F. Pinglot and M. Pourchet. 1987. Accumulation and temperature measurements on the James Ross Island ice cap. Antarctic Peninsula. J. Glaciol., 33 115). 357-362.

Aristarain, A.J., J. Jouzel and C. Lorius. 1990. A 400 years isotope record of the Antarctic Peninsula climate. Geophys. Res. Lett., 17 (12), $2369-2372$. 
ESA. 1993. ERS-1 user handbook. Paris, European Space Agency, (ESA SP-1148, revision 1.

Hoffmann, J. A. J. 1991. De las variaciones de la temperatura del aire en la Argentina y estaciones de la zona subantártica adyacente, desde 1903 hasta 1989 inclusive. Primera Conferencia Latinoamericana sobre Geofisica, Geodesía e Imestigacion Espacial Antárticas, Buenos Aires. Argentina, Julio 30-Agosto.3, 1990. Actas, 160-168.

Instituto Geográfico Militar. 1992. Carta lopográfica preliminar, Isla Ross (James Ross Island). Escala 1:100.000. Buenos Aires, Instituto Geográfico Militar.

Rabassa, J., P. Skvarca, L. Bertani and E. Mazzoni. 1982. Glacier inventory of James Ross and Vega islands, Antarctic Peninsula. Ann. Glaciol., 3, $260-264$.

Rott, H. and T. Nagler. 1994. Capabilites of ERS-1 SAR for snow and glacier monitoring in alpine areas. In Proceedings of the Second ERS-I Symposium, Space al the Service of our Environment, 11-14 October 1993, Hamburg. Germany. Paris, European Space Agency, 965-970. ESA SP-361.

Rott, H., C. Mätzler, D. Strobl, S. Bruzzi and K. G. Lenhart. 1988. Study on S.IR land applicalions for snow and glacier monitoring. Paris, European Space Agency. (ESA Contract Report 6618/85/F/FL(SC).)

Rott H., K. Sturm and H. Miller. 1993. Active and passive microwave signatures of Antarctic firn by means of field measurements and satellite data. Amn. Glaciol., 17, $337-343$.

Rott, H., H. Miller, K. Sturm and W. Rack. 1994. Application of ERS-1 SAR and scatterometer data for studies of the Antarctic ice sheet. In Proceedings of the Second ERS- I Symposium, Space at the Service of our Environmenl, 11-14 October 1993, Hamburg. Germany. Paris, European Space Agency, 133-139. (ESA SP-361.)

Skvarca, P. 1993. Fast recession of the northern Larsen Ice Shelf monitored by space images. Ann. Glaciol., 17, 317-321.

Strelin, J. and E. C. Malagnino, 1992. Geomorfologia de la Isla James Ross. In Rinaldi, C.A., eds., Geologia de la Isla fames Ross. Buenos Aires, Instituto Antártico Argentino, 7-36.

Thompson, L. G. and 7 others. 1995. Climate since AD 1510 on the Dyer Plateau, Antarctic Peninsula: evidence for recent climate change. Ann. Glaciol., 20, 420426. 